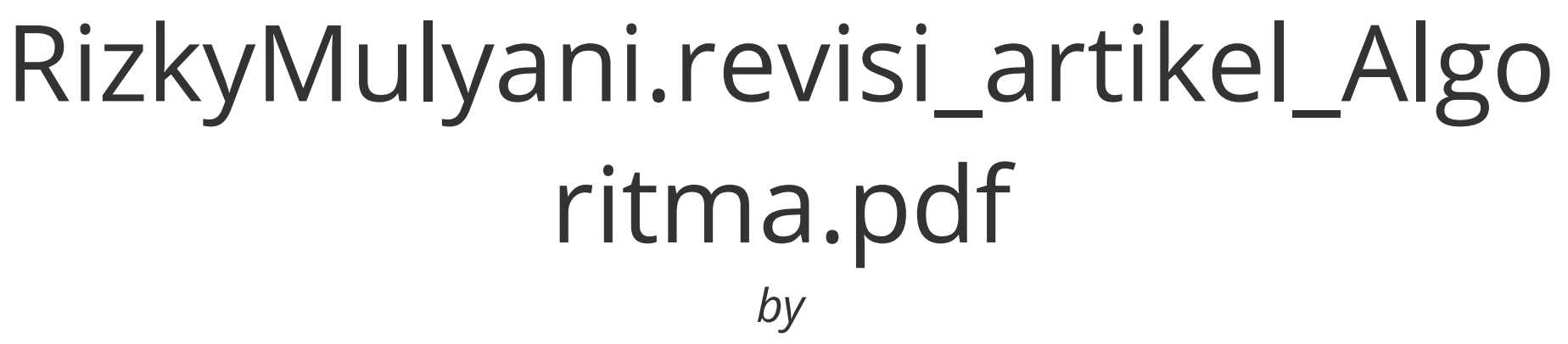

Submission date: 21-Dec-2021 11:20AM (UTC+0700)

Submission ID: 1734521971

File name: RizkyMulyani.revisi_artikel_Algoritma.pdf (265.33K)

Word count: 3126

Character count: 20257 


\title{
PEMBELAJARAN DASAR-DASAR ALGORITMA DAN PEMROGRAMAN
}

\author{
Oleh : Rizky Mulyani \\ MAHASISWI PMM FITK UINSU \\ nizkymalyani87@gmail com
}

\begin{abstract}
ABSTRAK
Algocitna ialah suatu langkah-langkah yang tersusun dalam menyclesaikan seboah permasalahan yang disusun secara runut dan tersusun. Algoritma adalah langkah-langkah komputasi yang terartikan dengan baik dengan nengeunakan beberapa nilai untuk input dan menciptakan beberapa nilai yang dikenal dengan kekuaran. Jadi, algoritma ialah urutan langkab-langkah kamputasi yang mengubah data masukin menjadi kekaran. Dalam konsep dasar algoritma pemograman ini,mudah bagi orang untuk mulai belajar algoritma periograman Karena seseorang akan lebih dulu mengetahui apa-apa saja hal-hal dacat dalam konsep dasar algoritma yang terdapot dalam algoritma pernograman.
\end{abstract}

KATA KUNCI : Pemrograman,Algoritma,Konsep dasarAlgoritma

PENDAHULUAN

Dislaum setiap bidang kehidupxin

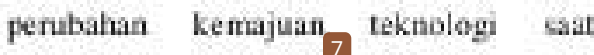
mengikses suatu pengelahuan dan komunikasi antara satu sama lain terjadi dengan sangat pesat.Komputef digurakan sctagi salah satu media yang mengakses komunikasi dan pengetahuan,nemerlukan adanya suata keahlian dalam komputer yang memungkinkan.Oleh karena itu 7 rembelajaran kompuner yang paling utama untuk mahasiswäi peadidikan matematika yany merupakan suatu pernhelajaran yang berkaitan dengan kapabilitas berpikir yang logis dan sistematis in sangat penting .
Komputer adalah suatu alat yang oleh manusia diberikan serangkaian perintah sehingea komputer lersebut dapat menyelesaikan suatu permasalahan bahkan secara benulang-ulang secara cepat,akuma dan tanpa kenal bosan juga lelah.Sekumpulan intruksi yang mana merupakan penyelesaian dari makalah itu dinamakan dengan programSupaya program tersebut dilakukan deh komputer,moka program tersebut haruslah dituliskan kedalam suatu bahasa yang dapat dimengerti oleh komputer tersebut Dan sastu bahasa yang dipakai 
dalam menulis program tersebut $\frac{\text { disebut }}{8}$ dengan perxognamansuate uretan langkah-kangkah yang tersusun sistemutis dilam menyelesiikan sebuah masabh discbut dengan algoritma.

Berbicara mengenai algoritma dalam bidang pemograman,Algonitma itu sendiri berarti solusi Oleh karena itu yang dimaksud dengan algoritma ialah suatu solusi dari sebuah permasalahan yang harus diselesaikan dengan menggunakan media yaitu berupa komputer.Algoritma itu sendiri harus dibuat secara selaras: supaya komputer dapat mengeksekusinya dan mengerti dengan apa yang diperintahkan.

Sejarah Algoritma Algoritma dapat dikatakan jantung komputer.Didalam terminology algoritma terdapat banyak cabang yang diacu dari itmu komputer Contohnya ; routing (algoritma perutean) yaituPesan di jaringan komputer unmk menggamtxar garis lurus(bidang grafika komputeriyaitu algoritma brensenham, Lntuk mensearch pola dalam teks (bidang information retrievel) yaitu algoritma knuth-momis-pratt dan lain schagainya.

Asal muasal dari kata "algoritma" sendiri memiliki cerita sejarah yang bisa dibilang cukup anch.Orang-orang hanya dapat menemukan kata algorism yang memiliki arli suatu proses menghitung dengan menggunakan angka arab.Untuk menemukan asal kata algoritma pura abli bakasa sendiri berusaha semaksimal mungkis.skan tetapi hasilnya masih belum memuakan.Hingga akhirnya abli sejamhuan matematika mendapatkan asal usul kata algoritma tersebut.Algorism berasal dari nama penulis boku Arab yang terkenal, yaitu Abu Ja'fat Muhammad Ibnu Musa al-Khuwarizmi forang baru membaca al-Khuwarizma menjedi algorism).Dari judal buku Kitab al-jabar wal muqabala yong berarti "buku pemugaran dan pengurangan", dapat diperoleh asal kata dari "aljaburalgebra)", Kata algorism berubah menjadi algorichm.Kata algorithm timbul karena Katu algorism sering kali keliru dengan kata arithmetichingga akhiran -sm berabah menjadi suatu hal yang sudah biass. Oleh karena itu semakin lama secara umam kata algorithm dipakai schagai suatu metode perhitungan. Dalam bahasa Indonesiakata algocithm disebut dengan "algoritma",

Pada tahun 1950, "Algoritma
matcmatikawan Yunani (lahir 350 M). pertama kali menggunakan kata algoritma dalam bokunya Elements dalam menulis langkah-langkah untuk menemukan pernbagi persekutuan lerbesar (ged), in dan 
n. (daa bilangan bulat. Dalam hal ini. Euclid didak menyebutkan bahwa metode itu digunakan sebogai suatu algoritma, dan di zaman mobem ini orang menyeloumya "Algoritma Euclidean" (pembagi persekutuan tertesar dari dua bilangan belat non-negatif adalah bilangan bulat positif tertecar yang dapat ditemukan ) dibagi desgan angka dua).

\section{- Pengertian Algoritma}

Menurut Rimsldi Munir dalam bukunya "Algorithms and Progrumming in Pascal and C Languages". algoritma adakh scrangkaian langkah untuk memecahkan seatu makalah.

Ada beberrapa pengertian lain dari algoritmakan tetapi prinsipmya sama dengan pengertia yang diungkapkan menurat Rinaldi Munir.Beberapa pengertian tersebut dikutip dari berbagai literature antara lain sebagai berikut:

- Algoxitma adalah scrangkaian langkah perhitungan yang mengubuh data masukkan aenjadi data keluaran.

- Algocitma adalah sckumpulan instruksi eksplisit uniuk mernecahkan suan masalah, yaitu untuk mendaparkan keharan yang diinginkan dari saatu masukas pada waktu tertenta.

- Algocitma myoéta komputasi ans diterepkeun saé ane nyandak sababuraha nilai pikeus input sareng nyiptakeun sababaraka nilai anu disebat kaluarin

14 Algoritma adalah ninutan langkahlangkah logis dakam memocahkan permasalahan yang tersusun secara sisternatis.Sumber lain menyebutkan bahwa algoritma meruapakn prosedur (deretan) yang berintegrasidatau suatu cara khusus yang digunakan dalam memecahkian maxilah yang bermar adanya(Webster Dictionary).

Membuntu memecahkan masilah dengan cepat dan akurat.Melalui algoritma sekuensial komputer dapat dengan cepat memahaninya.Dalam melakukan langkah Jogis harus dilakukan dengan urutan yang benar agar tujuan yang dicapai dalam menyelesaikan masalah tidak boleh salab.Seorang ilnowan bernamia Frech,C S(1984) mengatakan bohwa kemampuan,kesulitan dan keakutatan komputer dalam konsep-konsep komputer tertentu berkaitin dengan masalah pemograman.Pucas salat yang suna,ketika merancang algocitma,Seorang ilmuwan bernama Flecher (1991) mengusulkan beberapa metode dalam bentuk ekspresidaftar instruksibeberapa perintahprogram komputer,kode semu dan diagram alurdibankingkan dengan Knuth (1973),ia perciya bolwwa input,proses,dan output adalah algoritma dasar. 
Dalam konsep dasar algoritma pemograman ini,mudah bagi orang untuk mulai belajar algoritma pemograman.Karena sesextang akan lebih dulu mengetalaui apa-apa saja hal-bal dasar dalam konsep dacar algoritma yang terdapat dalam algoritma pemograman.

\section{METODE}

Beberapa standar memerlukan teknologi pemecahan masalah dan pemograman,standar tersebut digunakan sebagai dasar evaluasi untuk menentukan standar program yang baik (purnamasari,2005).

Algoritma adalnh metode efektif yang memecahkan daftar terbatas dari kumpulan perintah yang ditentukan untuk merghitungfungi.Dalam pemecalun masalah,criteria persyaratan awal tertenta hans dipenubi sebelum algoritm dicksekusi. Untuk semua kondisi awal yang sesuai dengan kriteria, algoritms festi akan selesai. Dimulai dari nilai awal. kemudian ada sckumpulan perintah yang ketika dieksekusi akan memproses pracksckusi kondisi diatur untuk menghasikan output, kemudian tencukan kondisi akhir.

Algoritasa merupakian suatu sebutan yang mengganti ketentuan yang terdapat padta arimetis yang bermanfaat buat menyelesaikan permasalahan dengan memakai bilangan angka Arab. Sebaliknya Algoritma Penwograman merupakan langkah- langkah yang disusun secara tertib buas menuntaskan sesuatu perntasalahan pearograman $\mathrm{pc}$. Permasalahan yang bendak dipindahkan oleh pe pertama dicoha formulasi langkah. langkah penyelesaian sesuatu permasalahan dengan $p c$ yang hendak. melaksanakan instruksi-instruksi tersebut.

Dalán systen komputer,algoritma adalah deskripsi langsung dari logika yang ditulis oleh pembuat perangkat lunak untuk mencapai tujuan perangkat lusak secara lebih efektif guna memperoleh keluaran dari masukkan yang diberikan (terkadang kosong).

8

Algoritma adalah urutan keputusan logis untuk memecuhkan saatu masalah. Kata-kata logis adalah kata kusci. Langkah-langkahnya barus logis, artinya nilad benar, benar dan salah haras ditentukan.Langkiah yang salah dayat menghasilkan hasil yang salah.

Menulis program juga merupakan disiplin yang membutuhkan aplik.asi yang cermat, karena program adalah aplikasi dari algoritma.Olch karena itupernograman Iebih dari sckedar kreativitas (yendri, 2013) Sistem permbelajaran jarak jauh menggabungkan 


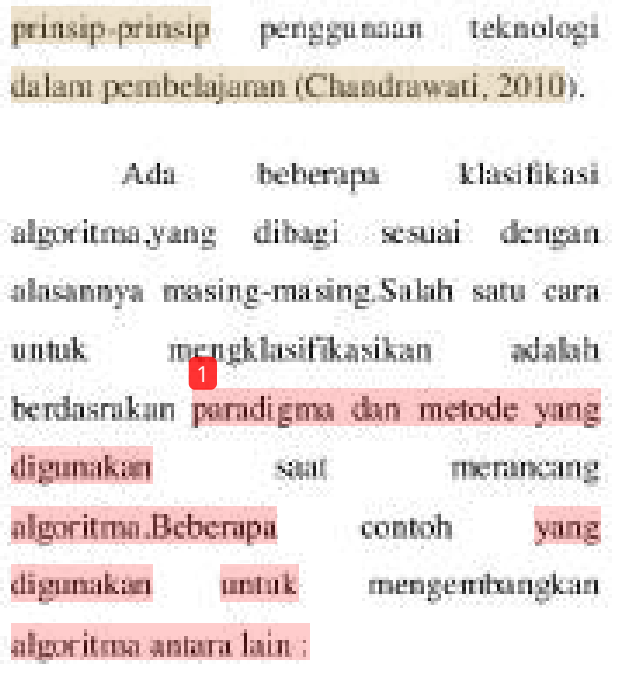

- Divide and Conquer, adalah paradigma yang memecah masalahbesar meajadi masalah kecil.Pembagian masalah berlanjut sampai bagian kecil dan sederhana dari masalah ditemokan.

- Pemograman Dinamis,Bila paradigma pemograman dinamislika digunakan pada masalah yang memiliki stroktur optimal dan asengandung beberapa bagian masalah yang tumpang tindib. maka sudah tepat. Paradigma ini mirip dengan paradigma bagi-dan taklukkan. yang herupaya membagi-bag̨i menjadi submasalah yong lebih kecil.tetapi jenis masalah yang dihadapi berbeda-beda.

- Metode serakah, adatah paradigma yang mirip dengan pourograman dinamis, tetapi jawaban untuk setiap stibpertanyaan tickak harus diketahui dari setiap tahapdan opsi terbaik digmakan poda saat ini.
- Pencarian dan pencacahan adalah
paradigma pemodelan yang menyediakan
aturan tertentu untuk pemecahan masalah
dan optignasi
Metode yang diguakan pada artikel ini adalah metode deskriptif, yairu mengumpulkan data dari berbagai refrensi lalu di bandingkan serta menganalisis untuk memperoleh keterangan atau data yang lebih akurat dan benar.

3 Pemecahan musalah adalah proses dari masalah bingga pembentukan algoritma.Unuk mendaparkan hasil pemograman yang membanta menyeledaiakan saatu masalah harus dapat melalui tiga tahapan utamadapat dengan mudah memahami suan masalah,dan memahami tujuan dibuatnya program.Selain pemabaman juga penting untuk dapat merumeskan koxixp atau desain dan menyelesaikan desain dari masalah yang akan dipecahkan.Akhirnyahasil desain daput diterapkan pada program yang disusun scara logis.

- Berlatih memahami dan mengamati masalah sesering mungkin untuk memahami masalah.

- Setelah meihat suatu masalah,hasil pengamatan tersebut dituangkan kedalam bentuk proses pemecahan masalah,yang disebut dengan algoritms. 
- Gunakan bahas pemograman untuk menerapkannya kekomputer dengan menulis program.

Proses penersopa suatu algoritma untuk menghasilkan solusi disebut tahap implementasi, Solusi yang dimaksad abalah program merupakan implementasi dari algoritais yang dikompilasi.

Merurut Heriyanto dan Abdul kadir ( 2005

: 6) suatu algonitma harus memiliki lima karakteristik penting yaitu berupa finiteness, definiteness, masukan. keluaran, dan efehtivitas.

- Keterbarasan, menyatakan hahwa algoritma harus berhenti untuk semua kondisi setelah memproses beberzpo langkah

- Defineteness, menunjukkan bahwa setiap lanokah hams diceritakan dengan jelas. (tidak ambigu atau ambigu).

- Input, Setiap algocitma tidak boleh memiliki input atau memiliki satu atag Jcbih input. Input adalah jumlah yang diherikan di awal sehelum algoritma diproses.

- Keluaran, Setiap algoritma memiliki output. baik. hanya satu eutput atau beberapa cotput.Output adalah kuantitas yang berhubungan atau berfubungan dengan impat.

- Efektivitas, setiap algotitma harus efektifkarena Semua operasi yang dilakukan oleh algoritma hans sederhana dan daput dilakukan dalam waktu yang terbatas. Pada prinsipoya, setiap instruksi dari algoritma dikpat dilakukan oleł orang-orang hanya dengan menggunakan kettas lan pera.

Analisis algoritma dalam menganalisis statu ilgorilmakita haras memperhatikan beberapa aspek,seperti :

Kebenaran (Correctness) ketika menbuktikan keaslian algoritma,perlu unfok memeriksa apakah_, lasil akhir dari algcritma memenuhi koadisi yang diberikan pada awal input.Unuk memeriksa algoritma kompleks. kita dapat membagi algoritma menjacs beberapa mod.l kecil. sehingga jika modul kecil bear, maka seluruh program benar.

Jumlah Operasi yang Dicobol Jumlah Pekerjaan Berakhir) Perhicungan jumlah operasi yang dicoba digunakan buat menyamakan tingkatan efisiensi algoritma serta algoritma lain buat membongkar permasalahan yang sama. Perihal ini dicoba buat menggapai sesuaru algoritma yang bisa menciptakan waktu cksekusi yang lebih kilat. Metode termudah buat menyamakan 2 algoritma yaitu dengan menghitung jumlah operasi bawah yang dicoba oleb algonitma tersebat, sebab bila menyansakan secara langsung of 
$\mathrm{pc}$, kerapkali keadaan tiap $\mathrm{pc}$ serta metode membaca di tiap bahasa pemrograman bisa pengaruhi waktu resolusi. dari permasalahan.

Analisis kasus terburuk Analisis kasus terburuk adalah analisis yang digunakan untuk melihat tingkat efektivitas suatu algoritma dalam menyelesaikan suatu masalah yang inputnya terkikhang tikak perlu dihiturg atau solusi ketaka kemungkinan imputnya salah.

Optimal (Optimalitas) diganakan Lntuk menganalisis saatu algoritma, biacanya digunakan kelas algoritma dan vkuran kompleksitasnya, misalnya: jumkh operasi dasar yang dilakukan. Jika tidak ada algoritma yang dapat melakukan lebih sedikit operasi dasar

- (untuk kasas terburuk) algoritma tersebut disebut optimal cuntuk kasus terburak\}.

Ikstan terendah digunakan untuk bisa membuktikan bahwa suaru algoritma itu idealtidak dibutuhkan memperhatikan setiap algoritma.Deagan cara membuktikan teorema teorema yang menentukan lower bound pada penjumlahan suatu operasi yang dibutuhkan untuk menyiapkan suatu permasaluhan.maka algoritma tersebut ditiamakan ideal jika dapat melakukan penjumilahan operasi

\section{HASIL DAN PEMBAHASAN}

Algonitma memiliki beberapa karakteristik, yaitu :

1. Beberapa masukkan diterima.

2. Proses inpot melalui langkahlangkah benurutan,

3. Setiap langkah harus didefinisikan dengan jelas, sederhana, dan efektif.

4. Urutan langkah barus ierbatis dan berhenti.

5. hasilkan keluaran atau output

Algonitma terbaik akan menghasilkan keluaran yang benar, efisien(efektif) dalan waktu yang relative singkat dan menggunakan memori yang relatif sedikit.

Sebenarnya kita sudah melakukan algoritma dalan kehidupan seburi-tsari. seperti mengirim email, menginstal aplikasi, menarik uang dari ATM, mengisi pulsa, membuat kue, mengendarai sepeda motor, merakit funitur, dan sebagianya. Semuanya dilakukan melalui langkahlangkah yang beruntan bukan?

agar lebih menberi gamburan, berikut adalah beberapa contoh algorima dalam notasi descriptif.

Contoh 1 : mengendarai sepeda motor :

1. Masukkan kunci

2. nyalakan mesinnya 
3. Masukkan gigi pertama

4. Putar pegangan gas

5. Motor dijalankan

6. Kexepatan dinaikan

Contoh 2 : menarik atau mengambil ung di ATM :

1. Masukkan kartu ATM

2. Masukkan nomer PIN

3. Pilih menu penarikan uang

4. Pilih jumlah besaran atau nominal yang diinginkan

5. Tarik uang yang dikeluatkan dari mesin (ATM).

22

Contoh 3 : Mensakarkan isi dari dua gelas $A$ dan $B$ :

1. Tuang larutan dari gelas A ke dalam gelas pembantu C $\mathrm{C}$ gehs $\mathrm{A}$ kosong)

2. Tuang larutan dari cangkir B ke dalaim cangkir A rcangkir B dikosongkan dan cangkir A diisi dengan larutan dari cangkir B)

3. Tuang larutan dari beaker $\mathrm{C}$ ke dalam beaker $\mathrm{B}$ (isi kedua gelas beker sudah tertukar)

\section{3}

Contoh 4 : menghitung luas segi tiga:

1. Masukan nilai alas lalu,

2. Masukan nilai tinggi

3. Hitunglah tuas dengan menggunakan rumss $=($ alas * ting i / /2
4. Cetak laas segitiga

Contoh 5 : menginstal aplikasi android dengan menggunakan playstore

1. Masuklah ke aplikasi playstore

2. Selanjumya Cari aplikasi pada bagian pencarian di bagian header 2 (atas)

3. Sisem menampilkan daftar aplikasi sesuai dengan kata kunci yang dimasukkan.

4. Pilih aplikas yang ingin Anda instal.

5. Klik tombol unduk.

6. Proses download sedang berjalan.

7. Jika gagal akan muncul pesan download kembali, jika berhasil akun nuncul tombol install

8. Klik tombol Install dan tunggu beberapa saat hingea proses instalasi seksai.

Contoh 6 : axenyambangkan perangkat ke jaringan wifi

1. Pilih jaringan wifi yang tersedia

2. Masukan username dan password dari wifi tersebut

3. Jika tadak sesuai atau lerdapat kesalahan dalam mensavakkan ugername dan juga password maka, sislem menampilkan gagal koneksi

4. Jika sesuai , Koneksi internet akan tersambung dan dapat digunakan. 
Contoh 7: mengirim e-mail

1. Buka aplikssi email ataa gmail

2. masuk ke sihus layanan email sesuai dengan akun yang terdaftar

3. Tulistah email (pesan baru)yang ingin dikirimka

4. Masukan alamat email tajuan. subjok, dan tulis isi email

5. Lalu Klik tombol kirim

Melanjutkan contob algoritma pengiriman email di atas, coba perhatikan dan pahami ilustrasi perbandingan pengiriman pesan secara manual melalui surat dengan pengiriman pesan melalua email di buwah ini:

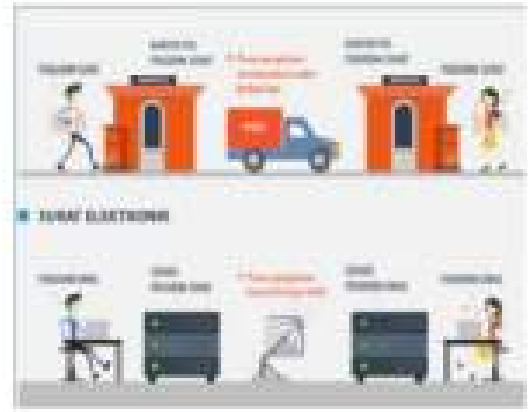

Dalam penggamboran di atas, dapat dilihat bahwa algoritma mengirim email tidak berbeda dengan mengirim surat biasa. Namun yang membedakan adalah media penyimpaman sekaligus perantars pesannya. Jika dalam surat tradisjosal pesan ditulis di atas kertas kemudian dikirim molalui kantor pos dan jasa pengifiman yang membutuhkan waktu berhari-bari unruk sumpai, sedangkan ensil ditulis menggunakan aplikasi layanan email dan dikirim melalui intemes. Proses pengiriman pesan hanya memakan waktu beherapa detik. Tentu saja ini sangat madah, dan seiring dengan perkembangan zaman, email tidak banya digunakin untuk mengirim pesan. tetapi juga digunakan untak mengirim file grafik seperti dokumen, gambar, video, dan audio.

Algoritma ialab urutan logis dalam mengambil kepurusan untuk memecahan statu masalah. Kata yang logis adalah kata kuncinya. Langkah-langkah yang diganakan harus logis. yaito yang dimaksud dengan nilai kebenaman hans ditentukan, benar atau salah. Langkah yang salah juga bisa memberikan hasil yage salah, Misalnya, perhatikan masalah pertukaran isi dua wadah, A dan B. Wadah A berisi larutan yang berwarna merah. sedangkan wadah B berisi air yang berwama bire. Selanjanya. kita ingin menakar isi kedua wadah sehingga Wadah A berisi larutan bin dan Waiah B berisi larutan metah.

Contoh Misalkan ada dea gelas, Gelas A dan Gelas B. Gelas berisi air berwarna merah dan Gelas B berisi air berwarma biru. yang dapat diubah kadar aimys pada Gelas A, sedangkan Gelis B berisi air berwama biru, Air merah. 
Algonitma Tukar_lsi_Gelas

10

1. Tuang air dari gelas $\mathrm{A}$ ke dalam gelas $\mathbf{B}$

2. Tuang air dari gelas B ke dalam gelas $\mathrm{A}$

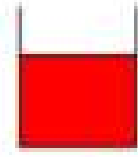

A

14

Algoritma di alas tidak mengarah pada pertukaran yang benar, langkah yang digunakan tidak logis, karena yang terjadi pada contob di atas kukanlah pertukaran. melainkan campuras air di gelas $\mathrm{A}$ dengan air de gelas B. Dengan demikian, algoritma Exchange_Isi_Glass dijelaskan di atas dinyatakan tidak benar... Duri contoh soal di atss dapat ditentakan algoritma yang tepat yaitu unituk mengeanti kadar air pash gelas A dengan kadar air pada gelas B diperlukan gelas tanku yang digunakan setagai tempar meletakkannya. air dalam gelas sepertic.

\section{Sehingga algoritma yang benar dari} permasulah diatas adalah sebagai berikut :

\section{Algoritma Tukar_lsi_Gelas}

1. Tuang air dari gelas A kedalam gelas C
2. Tuang air dari gelas B kedalam gelas A

3. Tuang air dari gelas $\mathrm{C}$ kedalam gelas

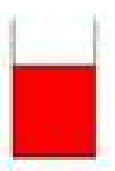

A

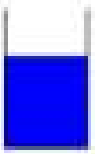

B

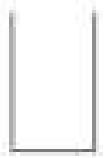

c
Proses pertukaran yaitu

12

1. Tuangkanlah air dari gelas A kedalam Eelas C

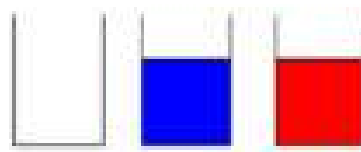

A $B$

C

2. Tuang air dari gelas B kedalam gelas A

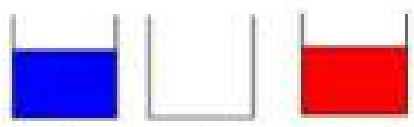

A

B

c

3. Tuang air dari gelas $\mathrm{C}$ kedalam gelas B

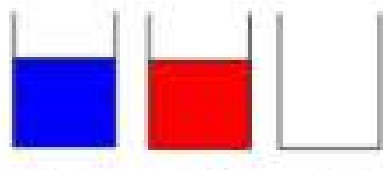
A
B 
23

Keadian senclah pertukaran dapat dilikat pada gambar dibawah ini :

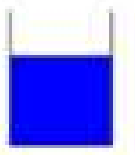

A

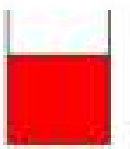

B

C

Sekarang

algoritma

Exchange_Item_Glass di atas sudhh dikoreksī dengan benar, sehingga kandungan air di gelas $\mathrm{A}$ dan isi air di gelas $\mathbf{B}$ bisa ditukar dengan benar.

Didalam kehidupan schari-hari Algoxitma banyak ditemukan, misalnya sebagai berikut :

\begin{tabular}{|c|c|c|}
\hline Woost & Alowan & 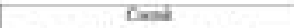 \\
\hline unatio & $\operatorname{lng} x=$ & 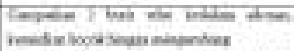 \\
\hline 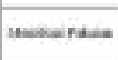 & aedices & 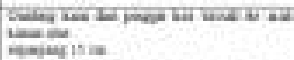 \\
\hline 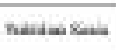 & Nomes hule & 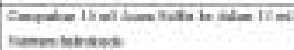 \\
\hline
\end{tabular}

\section{KESIMPULAN}

Algoritma menupakan suatu sebutar yang mengganti ketentuar yang terdapat poda aritmelis yang bermanfaat beat menyclesaikan permasalahan dengan memakai bilangan angka Arab. Program adalah persatuan algoritma dengan bahasa pemrotaman (programming langaage). Prognam melambangkan metode yang berawal dari saatu algoritma yang berbentuk bahasa pemrograman, kemudian bersedia untuk dipnaktikkan dalam mesin yang ada di komputer. Sebalikaya Algoritna Pexnrognaman merupakan langkah-langkah yang disusun sccara tertib buat menuntaskan sesuatu permasalaban pemrograman pc. Sifat-sifat algoritma adalah Input / Masukan, Output / Pengeluaran, Definiteness / Pendetinisan pengguna algoritma. Finiteness / Penyelesaian Effectiveness /Efektifitas, Generelity / Unum. Ada 3 struktur bawah pada algoritma ialab runtunas (sequence). pemilihan (selection) serta pengulangan (repetition). Padai dasamya algoritma dipecah jaci 3 berkagai bersumber pada format penolisannya, ialab : Deskriptif. Pseudocode serta Flowchart.

Algoritma dapat dikatakan jantung komputer.Didalam terminology algoritma terdapat banyak cabang yang diacu dari i (algoritma perutean. yaitu pesan di jaringan komputer untuk menggambar garis lurus (bidang grafik komputet), yaitu, algoritma Brensenham untuk mencuri pola dalam teks (bidang pencarian informasi). yaitu, Knuah-Morris -Algoritma Pratt dan sebagainya.

\section{DAFTAR PUSTAKA}

Bibi, Sarah, 2015. "Efektivitas Penerapan Blended Learning Terbadap Tingkat Pemahaman Mahasiswa Mata Kuliah Algoritma Dan 
Pearograman ." Jarnal Pendidikan Informasi Dan Sains Vo, 4 No, 2 $274-286$.

Budiman, Edi. ad. Belajer Desar Algoritna \& Penarognaman. Samarinda: Pemula.

Inchahyonti, Uce dan Yunianita Rahmawati. 2020. Algorifme Dan Pemrograman Dolam Bahasa C++ -Jawa Timur: Umsida Press.

Kaswur, Baso Andi dan Narjannah. 2021. "Pengembsngan Modul Pembelajaran Interaktif Untuk Meningkatkan Mutu Pembelajaraa Algoritma Dan Pemrograman." Jurnal Penjomint Musu Vol. 7 No: 2 143-153.

Kocntjoro, Edo Yorsatan, Bambang Hanadi dan Rangsang Purnama. nd. "Raseang Bangun Aplikasi Pemhelajaran Bahasa Pemrograman Dengan Metode Blended Leaming " 1-10.

Lubis, Muhamasad Ridwan. 2019. 'Model Jaringan Saraf Tiruan Backpropagation Unituk Meningkatkan Penguasaan Mahasiswa Pada Mata Kuliah Algoritma Dan Penrograman." Jumal Kompuler Dan Informatika Vol. XXI No. $891-94$.

Malsalisa, Galih. 2020, 'Web Developer Informasi Berbasis Algotitma Peinrograman.' Technologi Vol. II No, $/ 12-16$.

Margaretta, Allen, Asmural Isroqmi dan Tika Dwi Nopriyanti. nd. "Pengaruh Penerapan Algoritms
Terhadap Pembelajaran Pearograman Komputer." Jurnal inovasi Pendidikan Masemanika Vol. 2 No. $2126-135$.

Maulana, Gun Gun. 2013. "Pembelajaran Dasar Algoritma Dan Pemrograman Menggunakat El. Goritma Berbasis Web:" Jurnal Teknik Mesin Vol. O6 69-73.

Sari, Dewi Yunita. 2020. Algorinua Dant Pemrograwian Pascel Dan $\mathrm{C}++$. Yogyakarta: K-Media.

Syamsudin, Almad. n.d. "Analisis Kesalaban Coding Pemrograman Java Pada Mata Kuliah Algoritma Dan Pemrograman Mahasiswa Tadris Matematika IAIN Kediri," Focas Action of Reseurch Mathematic Vor. 2 Nor. 2.

Zamista, Adelia Alfama, Añ Sellisana dan Hanifatul Rahmi. 2021. Presepsi Mahasiswa Terhadap Pratikum Daring Mata Kuliah Algorima Dan Pcmrograman Ditinjau Dari Perbedaan Bender," Jurnal Dinamika Pendidikan Vol. 14 No. 2 $70-77$. 
RizkyMulyani.revisi_artikel_Algoritma.pdf

ORIGINALITY REPORT

$29 \%$

SIMILARITY INDEX
$29 \%$

INTERNET SOURCES
$2 \%$

PUBLICATIONS
$6 \%$

STUDENT PAPERS

PRIMARY SOURCES

1 123dok.com

Internet Source

2 www.ngopot.com

Internet Source

3 ngrumbi.blogspot.com

4 herlinasiswoyo.blogspot.com

Internet Source

5 archive.org

Internet Source

6 andrianiayu515.wordpress.com

7 jurnal.univpgri-palembang.ac.id

8

ahmadmuhsinupn.blogspot.com

Internet Source 
10 idhepz.blogspot.com

11 Submitted to Universitas Negeri Jakarta

Student Paper

12 devilzc0de.org

Internet Source

13 utsuasbsi98.blogspot.com

Internet Source

14 ilmukuring.wordpress.com

Internet Source

15 Submitted to STIKOM Surabaya

Student Paper

16 WWW.scribd.com

Internet Source

17 algoritma-program.blogspot.com

Internet Source

18 docplayer.info

Internet Source

19 irwanzulkifli.wordpress.com 
